\title{
Goats Fattening Under an Agrosilvopastoril Production System in Oaxaca
}

\author{
Ernesto de Jesús Viruel-Morales ${ }^{1}$, María Isabel Pérez-León ${ }^{1,3}$, José Cristóbal Leyva-López ${ }^{1}$, \\ Gerardo Rodríguez-Ortiz ${ }^{1}$, Jorge Hernández-Bautista ${ }^{2}$, Ernesto Castañeda-Hidalgo ${ }^{1, *}$ \\ ${ }^{1}$ Division of Studies of Postgrade and Investigation, Technological Institute of Valley from Oaxaca, TecNM. Ex Hacienda of Nazareno \\ Xoxocotlán, Oaxaca, Mexico \\ ${ }^{2}$ Faculty of Veterinarian and Zootechnic Medicine, Autonomous University Benito Juárez from Oaxaca, University Avenue, Cinco Señores, \\ Oaxaca, Mexico \\ ${ }^{3}$ UNAM-UABJO Research Center, Faculty of Medicine and Surgery, Autonomous University Benito Juárez from Oaxaca Ex Farm of \\ Aguilera S/N, Avenue San Felipe del Agua, Oaxaca, México
}

\author{
Email address: \\ casta_h50@hotmail.com (E. Castañeda-Hidalgo) \\ ${ }^{*}$ Corresponding author
}

\section{To cite this article:}

Ernesto de Jesús Viruel-Morales, María Isabel Pérez-León, José Cristóbal Leyva-López, Gerardo Rodríguez-Ortiz, Jorge HernándezBautista, Ernesto Castañeda-Hidalgo. Goats Fattening Under an Agrosilvopastoril Production System in Oaxaca. Animal and Veterinary Sciences. Vol. 7, No. 2, 2019, pp. 52-58. doi: 10.11648/j.avs.20190702.14

Received: February 15, 2019; Accepted: April 3, 2019; Published: June 12, 2019

\begin{abstract}
The agroforestry systems consider the integrated management of all production within the production unit processes and conservation practices related to the use of natural resources. From this point of view, it should be approached as a system composed by subsystems and the interactions that occur among them, in order to provide a sustainable, social, economic and ecological alternative to the traditional extensive ranching. The project objective was to evaluate the fattening of goats under an agrosilvopastoril production system established in the 2013 summer-autumn cycle, at the Technological Institute of Oaxaca Valley (ITVO). Completely randomized design with factorial arrangement evaluating three factors (age, sex and supplement) and two levels were used. 16 goats feeding with nutritional ITVO block, native grasses and guaje (Leucaena esculenta) were used. The variance analysis was made by the statistical package SAS (Statistical Analysis System) version 9.4. For the comparison of measures with Tukey test $(\alpha=0.05)$ and a proximal analysis by Van Soest to obtain the quality of the forages. Weight gain related to sex was differential, males and females presented a value of $63.5 \pm 18.2$ and $54.25 \pm 17.3 \mathrm{~g}$ day/animal not significant ( $>0.05$ ), respectively. Creole goats grazing and supplemented with a nutritional block had a weight gain of $70.5 \pm 20.3 \mathrm{~g}$ day/animal without supplement $47.29 \pm 18.9 \mathrm{~g}$ day/animal not significant $(\mathrm{p}>0.05)$. The greater weight gained in nutritional supplement found with block showed that the use of the same influences fattening goats.
\end{abstract}

Keywords: Goats, Weight Gain, Nutritional Block, Extensive Livestock Farming, Nutritional Supplement

\section{Introduction}

The traditional agriculture in Mexico has the main function of assisting the subsistence of the rural families, mainly in those communities that integrate cultivations, cattle raising and forest use. During a lot of time, the goat has provided to the human of products that have allowed them improving well-being and economy; mainly for the social classes vulnerable of the rural environment [1]. In many underdeveloped countries, the goats continue being the main animals that cover the human necessities [2]. To reach an appropriate and sustained productivity in the communities, it is necessary to know the use that carries out the goat of the vegetable species. The capacity of the goat in the use of the bush is well known [3-5] and their efficiency to survive in certain areas that their topography, vegetation and other adverse conditions, make them inadequate for the handling of bovines and ovines [6-7].

The grasses and some trees possess a great potential as food source for small and big ruminants due to their protein 
level, appropriate proportion of fibrous components and content of minerals [8]. The agrosilvopastoril systems, as area of scientific knowledge, are a combination of traditional and modern technologies that have been systematized with the purpose of offering a viable and sustainable alternative for the traditional cattle raising; however, it continues demeaning the soil and the resources due to the incompatibility between the used technologies and the productive atmosphere and for the advance of the agricultural frontier in frequently not very appropriate areas [9].

In a general way, the production systems face different challenges, highlighting the changes in the technological, social, economic, environmental and political or institutional factors and their characterization would allow approaching the existent problem [10-12]. The $90 \%$ of the systems of goats production in Mexico and in the county they are pastoral of sedentary type that exhibit poor and faulty handling programs (facilities, nutrition, reproduction and genetic improvement, health and market) when being marketed the product [13-14]. There are diverse options to reduce the environmental deterioration taken place by the expansionary peak of the extensive cattle raising in the Mexican tropic [15]; stand out for their importance the implementation of agrosilvopastoril practices that can improve the animal behavior (gain of weight, production of milk) without generating dependence of external inputs. In Puebla, Mexico, obtained an individual individual gain of weight from the birth until the year of age of $55 \mathrm{~g}$ for creole kids, $60 \mathrm{~g}$ for the blend and $63 \mathrm{~g}$ for the Nubia race, in an agrosilvopastoril system [16]. In another study used 31 creole goats 3.5 years old with an average of $28.87 \pm 2 \mathrm{~kg}$ of live weight during 87 days [17].

The animals with graze and pruning only generated 25.40 g day/animal, while those fed in graze and with molasseshay-urea obtained $91.61 \mathrm{~g}$ day/animal, thanks to the contribution of raw protein. The objective of this study was to evaluate the fattening of goats under an agrosilvopastoril production system fed with guaje (Leucaena esculenta), grasses, especially guinea (Panicum maximus), buffel grass (Cenchrus ciliare) and pink grass (Rhynchelytrum repens) and a nutritious supplement by means of a nutritional block.

\section{Materials and Methods}

\subsection{Agrosilvopastoril System}

The present experiment was carried out in the lands of the ITVO, where is established an agrosilvopastoril system made up of several species. The institution is located in the ExFarm of Nazareno, municipality of Santa Cruz Xoxocotlán, Oaxaca. The agrosilvopastoril system used for the feeding of the goats was established in 2006. It is structured by guaje plants (Leucena esculenta L.) settled down in a cultivation system in alleyways, where the trees were planted in lines to curved of level in fringes with a separation of 5-6 m, to staggered and $0.5 \mathrm{~m}$ among plants. The guaje is a native leguminous plant of the region, it is abundant and used as protein source. Among the lines of the trees, diverse species exist, especially gramineous used in the shepherding of the goats. Stand out for their importance the Guinea grass (Panicum maximus), Buffel grass (Cenchrus ciliare) and Pink grass (Rhynchelytrum repens); some herbaceous plants as the purslane (Portulaca oleracea L.) and quintonil (Amaranthus hybridus L.), like some bushes as huizache (Acacia farnesiana L.) and guamuchil (Pithecellobium dule). For the nutritious complement the block nutrimental of $10 \mathrm{~kg}$ was used conformed by $3.6 \mathrm{~kg}$ of molasses, $0.5 \mathrm{~kg}$ of urea, $0.3 \mathrm{~kg}$ of salt mineral, $0.5 \mathrm{~kg}$ of contained ruminal, $0.5 \mathrm{~kg}$ of lime, $1.6 \mathrm{~kg}$ of soya and $3.0 \mathrm{~kg}$ of corn, offered to the goats in the selected treatments every day in one period not bigger at two hours to avoid some intoxication by urea.

\subsection{Experimental Design and Analysis of Data}

The evaluated animals were 16 goats, eight males (four of three months with a weight of $10.25 \pm 1.9 \mathrm{~kg}$; four of seven months with $17.2 \pm 2 \mathrm{~kg}$ ) and eight females (four of three months of age and $13.17 \pm 1.7 \mathrm{~kg}$ of weight and the other half of seven months and $15.22 \pm 2.4 \mathrm{~kg}$ of weight). The productive variables registered in each animal were gain of weight, daily consumption, conversion and nutritious efficiency. In the forages the percent of raw protein was determined (PCP), percent of raw fiber (PCF), percent of ashy (CP), percent of fatty (GP), percent of fiber neuter detergent (FND) and the percent of sour fiber detergent (AFD).

An experimental design was used totally randomized with factorial arrangement evaluating three factors (age, supplement and sex) and two repetitions. The variance analysis was made by means of the statistical package SAS (Statistical Analysis System) version 9.4. The comparison of medias by means of the test Tukey $(\alpha=0.05)$. There was carried out a proximal analysis and Van Soest to obtain the quality of the established forages used in the feeding of the goats. There were taken the measures of each one of the parcels installed with the purpose of determining the capacity of animal load and the capacity of available forage during the time summer - autumn.

\section{Results}

\subsection{Edaphics Characteristics}

The land where the agrosilvopastoril system is located has a slope average of $30 \%$, thin soils, not bigger to the $30 \mathrm{~cm}$ in its lower part, with contents of $84.56 \%$ of sand, $9.44 \%$ of clay and $6 \%$ of slime, classified as a frank sandy soil, that makes it of low capacity of retention of humidity. The $\mathrm{pH}$ was of the 6.34, considered as good; the electric conductivity of $0.47 \mathrm{dS} \mathrm{m}^{-1}$, the content of organic matter was of $1.41 \%$, classified as low.

\subsection{Weight}

It was identified that in the sex variable in relation to the initial weight, to the 60 days after the treatment and to the 
final weight no statistical difference exists $(p>0.05)$. In the same way, in the variable supplement in relation to the initial weight, no statistical difference was found $(\mathrm{p}>0.05)$. However, to the 60 days of fattening there was observed statistical difference $(p<0.05)$. In the final weight statistical difference is also observed ( $\mathrm{p}<0.01)$. In the age variable it was found that highly significant difference existed $(\mathrm{p}<0.01)$ in relation to the initial weight, to the weight to the 60 days of fattening and to the final weight with a $p<0.05$. In the interaction Sex $\times$ Suplement, Suplement $\times$ Age and of Sex $\times$ Suplement $\times$ Age they were not significant differences
( $>0.05$ ) during all fattens while in the interaction of Sex $\times$ Age there was observed statistical difference $(p<0.05)$ in all fattens (Table 1). In the sex variable there was no statistic difference $(p>0.05)$ in relation to the rest of the variables of evaluated production. It is observed that the females have an individual initial weight of $14.50 \pm 2.26 \mathrm{~kg}$ and $13.62 \pm 4.16 \mathrm{~kg}$ for the males. The individual final weight to the four months of fattening on weight of the females was of $20.7 \pm 3 \mathrm{~kg}$ and of $21.4 \pm 3.8 \mathrm{~kg}$ in the males. As for the weight to the 15 days of fattening, the standard deviation is more variable in the males than in the females (Table 2).

Table 1. Variance analysis of animal weight during fattening.

\begin{tabular}{|c|c|c|c|c|}
\hline Variation source & Init & & Middle weight (60 days) & Final weight (120 days) \\
\hline & g.1 & $\mathrm{CM}$ & $\mathrm{CM}$ & $\mathrm{CM}$ \\
\hline Sex & 1 & $0.90^{\mathrm{ns}}$ & $0.72^{\text {ns }}$ & $1.62^{\mathrm{ns}}$ \\
\hline Supplement & 1 & $7.56^{\mathrm{ns}}$ & $31.36^{*}$ & $69.30 * *$ \\
\hline Age & 1 & $81.00 * *$ & $46.92 * *$ & $38.13 *$ \\
\hline Sex $\times$ Supplement & 1 & $12.60^{\mathrm{ns}}$ & $12.96^{\mathrm{ns}}$ & $6.89^{\text {ns }}$ \\
\hline Sex $\times$ Age & 1 & $24.01 *$ & $19.80^{*}$ & $30.52 *$ \\
\hline Supplement $\times$ Age & 1 & $6.76^{\mathrm{ns}}$ & $8.41^{\mathrm{ns}}$ & $22.80^{\mathrm{ns}}$ \\
\hline Error & 8 & 2.98 & 3.74 & 4.83 \\
\hline Total & 15 & & & \\
\hline
\end{tabular}

${ }^{\mathrm{ns}}=$ no significant, $*=$ significant al $0.05, * *=$ significant at 0.01 .

As for the age, there was statistical difference $(p<0.05)$. The initial weight of the goats of three months was of $11.71 \pm 2.32 \mathrm{~kg}$ and in those of seven months of $16.21 \pm 2.36$ $\mathrm{kg}$, obtaining an individual final weight to the four months in the goats of three months of fattening of $19.48 \pm 1.6 \mathrm{~kg}$ and of $22.57 \pm 4.6 \mathrm{~kg}$ the goats of seven months. As for the standard deviation of the age variable, in relation to the initial weight, until the 60 days of fattening there do not exist variability, while starting from the 75 days until the end of fattening, the standard deviation increases in the goats of seven months and the points move away from the average because some goats took in an efficient way the offered food and they achieved a better weight.

Table 2. Tests of medias of variables in relation to sex, age and food suplement to the 120 days of fattening.

\begin{tabular}{|c|c|c|c|c|c|c|}
\hline Variation source & Sex & & Age & & Suplements & \\
\hline Kg & Females & Males & Three months & Seven months & With & Without \\
\hline Initial weight & $14.50 \pm 2.26 \mathrm{a}$ & $13.62 \pm 4.16 \mathrm{a}$ & $11.71 \pm 2.32 \mathrm{a}$ & $16.21 \pm 2.36 \mathrm{~b}$ & $14.65 \pm 4.02 \mathrm{a}$ & $13.27 \pm 2.31 \mathrm{a}$ \\
\hline 15 days after treatment & $14.50 \pm 2.23 \mathrm{a}$ & $14.13 \pm 4.03 \mathrm{a}$ & $12.21 \pm 2.20 \mathrm{a}$ & $16.42 \pm 2.51 \mathrm{~b}$ & $15.11 \pm 3.85 \mathrm{a}$ & $13.52 \pm 2.24 \mathrm{a}$ \\
\hline 30 days after treatment & $14.91 \pm 2.29 \mathrm{a}$ & $14.50 \pm 3.92 \mathrm{a}$ & $12.71 \pm 2.32 \mathrm{a}$ & $16.70 \pm 2.50 \mathrm{~b}$ & $15.60 \pm 3.75 \mathrm{a}$ & $13.81 \pm 2.20 \mathrm{a}$ \\
\hline 45 days after treatment & $16.10 \pm 2.68 \mathrm{a}$ & $15.55 \pm 3.83 \mathrm{a}$ & $13.88 \pm 2.46 \mathrm{a}$ & $17.76 \pm 2.72 b$ & $16.93 \pm 3.65 \mathrm{a}$ & $14.71 \pm 2.42 \mathrm{a}$ \\
\hline 60 days after treatment & $17.12 \pm 2.91 \mathrm{a}$ & $16.70 \pm 3.58 \mathrm{a}$ & $15.20 \pm 2.15 \mathrm{a}$ & $18.62 \pm 3.17 \mathrm{~b}$ & $18.31 \pm 3.48 \mathrm{a}$ & $15.51 \pm 2.20 \mathrm{~b}$ \\
\hline 75 days after treatment & $17.91 \pm 3.31 \mathrm{a}$ & $17.55 \pm 3.73 \mathrm{a}$ & $15.90 \pm 1.92 \mathrm{a}$ & $19.56 \pm 3.69 b$ & $19.31 \pm 3.70 \mathrm{a}$ & $16.15 \pm 2.35 \mathrm{~b}$ \\
\hline 105 days after treatment & $20.02 \pm 3.68 \mathrm{a}$ & $19.48 \pm 4.22 \mathrm{a}$ & $17.97 \pm 1.69 \mathrm{a}$ & $21.53 \pm 4.63 b$ & $21.96 \pm 3.73 \mathrm{a}$ & $17.55 \pm 2.56 \mathrm{~b}$ \\
\hline Final individual weight per period & $20.71 \pm 3.58 \mathrm{a}$ & $21.35 \pm 4.14 \mathrm{a}$ & $19.48 \pm 1.65 \mathrm{a}$ & $22.57 \pm 4.69 \mathrm{~b}$ & $23.11 \pm 3.59 \mathrm{a}$ & $18.95 \pm 2.72 b$ \\
\hline Individual weight gain per period & $6.51 \pm 2.16 \mathrm{a}$ & $7.63 \pm 2.07 \mathrm{a}$ & $7.77 \pm 1.62 \mathrm{a}$ & $6.36 \pm 2.16 \mathrm{~b}$ & $8.46 \pm 1.41 \mathrm{a}$ & $5.67 \pm 1.81 \mathrm{~b}$ \\
\hline Food consumption & $51.38 \pm 1.74 \mathrm{a}$ & $51.38 \pm 1.74 \mathrm{a}$ & $51.00 \pm 1.92 \mathrm{a}$ & $51.75 \pm 1.44 \mathrm{~b}$ & $51.60 \pm 1.44 \mathrm{a}$ & $51.15 \pm 2.08 \mathrm{~b}$ \\
\hline Food conversion & $9.27 \pm 4.84 \mathrm{a}$ & $7.17 \pm 2.00 \mathrm{a}$ & $6.76 \pm 1.15 \mathrm{a}$ & $9.70 \pm 4.87 \mathrm{~b}$ & $6.24 \pm 1.04 \mathrm{a}$ & $10.22 \pm 4.45 b$ \\
\hline Food efficiency & $0.12 \pm 0.04 \mathrm{a}$ & $0.14 \pm 0.03 \mathrm{a}$ & $0.15 \pm 0.02 \mathrm{a}$ & $0.12 \pm 0.05 \mathrm{~b}$ & $0.16 \pm 0.02 \mathrm{a}$ & $0.11 \pm 0.03 \mathrm{~b}$ \\
\hline
\end{tabular}

Identical letters in a line do not show significant differences among medias (Tukey, 0.0.5). Media \pm standar desviation.

As for the supplement, in relation to the initial weight to the 45 days of fattens there was not statistical difference ( $p>0.05$ ), but starting from the 60 days until the final weight to the 120 days of fattens there existed statistical difference ( $\mathrm{p}<0.05$ ) among the goats with supplement and without supplement.

\subsection{Gain of Weight}

The implementation of fattening of goats in the agrosilvopastoril system of the ITVO by means of a feeding based on the shepherding of the gramineous and leguminous association generated a gain of weight of $57.7 \pm 7.1 \mathrm{~g}$ day/animal in the creole goats of three months. For the goats of seven months a gain of $36.87 \pm 13.8 \mathrm{~g}$ was obtained day/animal during one period of fattening of 120 days. The gain of weight for the goats in relation with their ages, are of $53.02 \pm 20.3 \mathrm{~g}$ day/animal for goats of seven months and $64.79 \pm 13.5 \mathrm{~g}$ day/animal for goats of three months. These 
data are considered as good, taking into consideration the conditions from the animals to the beginning of the experiment. While the gain of individual daily weight of the male riches a value of $63.5 \pm 18.2 \mathrm{~g}$ day/animal, in the females is of $54.25 \pm 17.3 \mathrm{~g}$ day/animal (Table 2). The conversion and nutritious efficiency of the goats of three months were those that presented the best values $(6.76 \pm 1.15)$, while in the nutritious efficiency the best value obtained was in the goats of seven months (Table 2). The gain of weight of the goats with supplement was of $70.5 \pm 20.3 \mathrm{~g}$ day/animal and without supplement of $47.29 \pm 18.9 \mathrm{~g}$ day/animal (Table 2). The use of the nutritional block helps to the goats to have a better gain of weight (GPD) $70.5 \mathrm{~g}$ day/animal that generates during the 120 days of fattening $8.46 \pm 1.41 \mathrm{~kg} /$ animal.

\subsection{Proximal Analysis}

With the values obtained by means of the proximal analysis and Van Soest it was determined that the forage with more raw fiber is the guinea grass in hay with $32.15 \%$ and in reflourishing 26.49\%; guaje in hay $14.29 \%$ and sprouts $8.66 \%$; pink pasture in hay $28.78 \%$ and in sprouts $29.96 \%$; Buffel pasture in hay $31.39 \%$ and in sprouts $29.62 \%$; nutrimental block $2.30 \%$. The forage with more content of fat is the Buffel grass in hay with $23.38 \%$ and in sprouts $1.77 \%$; guaje in hay $12 \%$ and in rebrote $12.77 \%$; rosy pasture in hay $4.46 \%$ and in sprouts $4.12 \%$; guinea pasture in hay $11.72 \%$ and in sprouts $15.12 \%$; nutrimental block $19.46 \%$. Regarding the value of the raw protein, the nutrimental block obtained the highest value with $22.97 \%$; the guaje in hay $16.60 \%$ and in sprouts $22.13 \%$; rosy pasture in hay $6.77 \%$ and in sprouts 9.37; guinea pasture in hay $5.30 \%$ and in sprouts $9.82 \%$; Buffel pasture in hay $4.85 \%$ and in sprouts $7.73 \%$. As for ash, the nutrimental block got the highest value with $17.32 \%$; the guaje in hay $5.41 \%$ and in sprouts $5.65 \%$; pink pasture in hay $6.53 \%$ and in sprouts $8.01 \%$; Guinea pasture in hay $9.58 \%$ and in sprouts $9.44 \%$; Buffel pasture in hay $9.65 \%$ and in sprouts $12.23 \%$ (Figure 1).

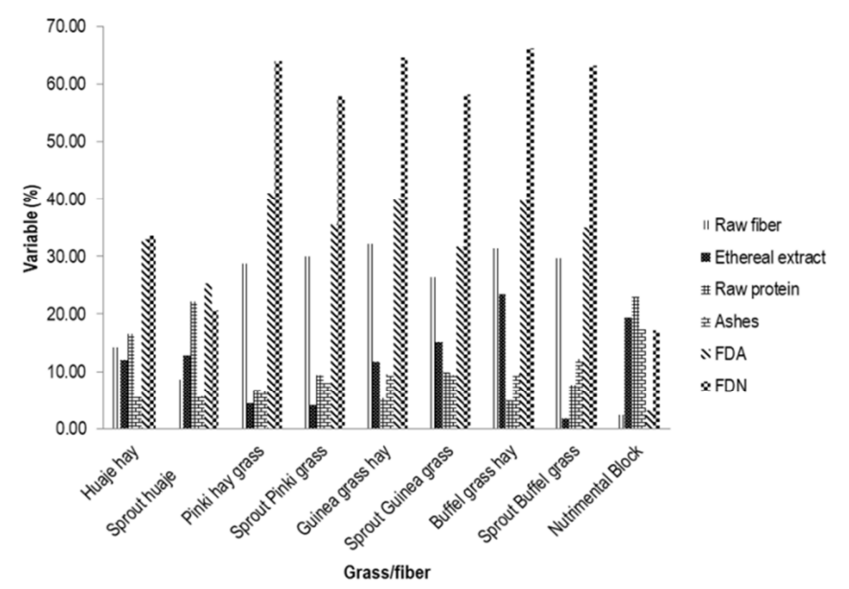

Figure 1. Proximal analysis and van Soest and wine of forages and nutrimental blocks.

In a same way, the Pink grass in hay obtained the highest value in sour fiber of detergent (FDA) of $41.11 \%$ and in sprouts $35.65 \%$; the guaje in hay $32.99 \%$ and in sprouts $25.26 \%$; guinea pasture in hay $40.14 \%$ and in sprouts $31.70 \%$; Buffel pasture in hay $39.92 \%$ and in sprouts $35.04 \%$, the nutrimental block of $3.16 \%$. Regarding the FDN, the Buffel grass in hay obtained a value of $66.22 \%$, and in sprouts $63.25 \%$; the guaje in hay $33.57 \%$ and in sprouts $20.70 \%$; rosy pasture in hay $64.13 \%$ and in sprouts $58 \%$; guinea pasture in hay $64.75 \%$ and in sprouts 58.31 and the nutrimental block of $17.15 \%$.

The guaje introduction in the prairies of the ITVO is shown as an effective alternative for the feeding of the goats. In accordance with the proximal analysis carried out, the fiber percentage found was of $14.29 \%$ in hay and $8.66 \%$ in sprouts; $22.13 \%$ protein in sprouts and of $16.60 \%$ in hay. This quantity of protein contributes to the gain of weight in the goats of $47.25 \mathrm{~g}$ day/animal. The nutritional value obtained by means of the methods of proximal analysis, Van Soest and Wine of the gramineous used in the experiment for the grass guinea showed a content of raw fiber of $32.15 \%$ in hay; $26.49 \%$ in sprouts; raw protein $5.30 \%$ in hay, $9.82 \%$ in sprouts; ethereal extract of $11.72 \%$ in hay, $15.12 \%$ in sprouts; ash of $9.58 \%$ in hay, $9.44 \%$ in sprouts; FDA of $40.14 \%$ in hay, $31.70 \%$ in sprouts, FDN of $64.75 \%$ in hay and $58.31 \%$ in sprouts.

The values obtained in the Buffel grass were for raw fiber of $31.39 \%$ in hay, $29.62 \%$ in sprouts, ethereal extract $23.38 \%$ in hay, $1.77 \%$ in sprouts, raw protein of $4.85 \%$ in hay, $7.73 \%$ in sprouts, ash of $9.65 \%$ in hay, $12.23 \%$ in sprouts, FDA of $39.92 \%$ in hay and FDN of $35.04 \%$ in sprouts. In general, the content of the chemical composition obtained in this study was low compared with the samples of Buffel grass with values of $11.4 \%$ for raw protein, $2.2 \%$ of ethereal extract, $12.5 \%$ of ash, $60.8 \%$ in FDN and $33.2 \%$ in FDA [18]. Another report in samples of Buffel grass values of $9.5 \%$ of raw protein, $13.17 \%$ in ash and 79.45 in FDN [19]. Lastly, the values obtained in the Pink grass in the agrosilvopastoril system designed were: raw protein of $9.37 \%$ in sprouts, $6.77 \%$ in hay; raw fiber of $29.96 \%$ in sprouts, $28.78 \%$ in hay; ethereal extract of $4.12 \%$ in sprouts and $4.46 \%$ in hay; ash of $8.01 \%$ in sprouts and $6.53 \%$ in hay; FDN of $58 \%$ in sprouts and 64.1 in hay and FDA of $35.65 \%$ in sprouts and $41.11 \%$ in hay.

\section{Discussion}

\subsection{Edaphic Characteristics}

The $\mathrm{pH}$ of the soil is directly related with the $\%$ of acidity saturation, a soil with $\mathrm{pH}$ lower than 5 is considered very sour, and the good $\mathrm{pH}$ for most of the cultivations should be between 6 and 7. The organic matter is the residual of plants and animals included to the soil, and it is expressed in percentage. The content of organic matter is an index that allows to estimate in approximate form the reservations of $\mathrm{N}$, $\mathrm{P}$ and $\mathrm{S}$ in the soil, and its behavior in the dynamics of nutritious [20]. The organic matter improves many chemical, physical and microbiologic properties that favor the growth 
of the plants. The soils with less than $2 \%$ of organic matter have low contain, and from 2 to $5 \%$ is a half content, being desirable that the value is higher than $5 \%$.

\subsection{Weight}

Some average values of weight obtained to the birth and the 100 days of age of kid Boers half blood are 4.1 and 31.1 $\mathrm{kg}$ for males, and 4.0 and $28.7 \mathrm{~kg}$ for females for an A flock [21]. While for a B flock, the males weighed 4.3 and $26.4 \mathrm{~kg}$ and the females 3.6 and $21 \mathrm{~kg}$, for both periods, respectively. That this behavior owes to the hormonal differences between both sexes and that it is attributed to the biggest efficiency in the digestibility of nutrients on the part of the males [22]. In this respect, the males synthesize less fatty fabric starting from the digested nutrients that the females, giving a bigger effectiveness as a result in the food transformation in corporal weight [23]. In an investigation work they used 31 creole goats, of 3.5 years old, with an average of $28.87 \pm 2$ $\mathrm{kg}$ of live weight, during 87 days, the animals with pasture and pruning only generated $25.40 \mathrm{~g}$ day/animal, while those fed with molasses-hay-urea $91.61 \mathrm{~g}$ day/animal [17].

\subsection{Gain of Weight}

The gain of weight is an important variable that determines if a feeding program is or not working. In addition, it is used to estimate the time that will require an animal to reach the market weight. It is also good to see if the animal is winning the correct weight for the production stage that is feeding. Each productive stage of the animals has a gain of weight that depends on the genetic capacity of that animal and of the consumption and quality of a food [24]. In an experiment with 36 lambs (18 males and 18 females) during 90 days, with the purpose of evaluating different proteical sources during the period of growth, with a live weight of $13 \pm 0.5 \mathrm{~kg}$ approximately, the results showed [25], that the interaction Diet $\times$ Sex influenced in the food consumption $(P<0,01)$ and the gain of weight $(\mathrm{P}<0,05)$, being the biggest consumption and gain of weight for the subjected lambs to the concentrated commercial $(300 \mathrm{~g})$. Similar results in an agrosilvopastoril system designed in Puebla, where the daily gain of weight from the birth until the year of age was of $55 \mathrm{~g}$ for creole boers; $60 \mathrm{~g}$ for cross and $63 \mathrm{~g}$ for the Nubia goats [16]. The kid Boer has a regular and progressive growth and that the average daily gain of weight is located between 100 $180 \mathrm{~g}$ day/animal, diminishing gradually until the seven months [26]. Starting from there is done to a reason from 60 to $80 \mathrm{~g}$ day/animal. The results shown here are in the inferior range for animals of the same age. This value is much smaller compared to the a gain of weight of $17.04 \mathrm{~kg}$ during 90 days in goats fed with supplement with nutritional blocks and a mixture of Star grass (Cynodon niemfluencis) and Buffel grass (Chenchrus ciliaris) [27]. The use of blocks (BN) in ovines of three months and a weight average of 17 $\mathrm{kg}$ using three different treatments, a GDP of $90 \mathrm{~g}$ is obtained day/animal; under pasture+BN+guaje $102 \mathrm{~g}$ was generated day/animal [28]. When being supplemented with nutritional blocks with flour of blood as protein source, the daily gaining of weight was $134 \mathrm{~g}$ day/animal, a value that is higher than those reported in this study [29]. In many countries have been used the $\mathrm{BN}$ in the feeding of ruminant, and has been shown that it is a technology in the easy nutrition and practice to help to solve the problems of feeding of ruminants, when the animals receive a base diet compound mainly of mature forages or fibrous residuals of cultivations [30]. The agrosilvopastoril system under a handling of appropriate animal load benefits the goats in its development. While the forage has a better yield and a quick sprout, it avoids the erosion of the soil. The appropriate use of an animal load in the scorch allows the recovery of the vegetation (covering, production, quality and diversity of species), it favors the crop of rain water and it contributes to reduce erosion [31]; also, the production of the livestock improves when having a bigger quantity of forage of good quality, what favors the development of a sustainable cattle raising. When an adapted animal load is used, the gain of individual weight of the livestock is bigger than when high loads are used, aspect that happened in the experiment with goats. In high loads the individual gain of the livestock is sacrificed by a bigger production by hectare; however, this production is not possible to sustain for a long period due to the damages to the vegetation and the soil.

\subsection{Proximal Analysis}

In goats in growth obtained a gaing of weight of $22.5 \mathrm{~g}$ day/animal with Leucaena esculenta, which presents $25.4 \%$ of raw protein in sprout and $20.1 \%$ in maturation [32]. Some studies have demonstrated that the supplementation with leguminous improves the use of the basic diet and the productive answer in ruminant. The nutritional parameters of Leucaena esculenta are $24.74 \%$ in raw protein and $13.25 \%$ in raw fiber [33]. In a silvopastoril system the state of Nayarit by means of a bromatologic analysis report for Leucaena esculenta raw protein of $21.72 \%$; ashes of $10.73 \%$; ethereal extract of $6.78 \%$; FDN of $45.13 \%$ and FDA of $16.98 \%$ [34]. In a system of intensive shepherding of guinea grass obtained values similar to those mentioned with $9.5 \%$ of raw protein, $9.4 \%$ of ash, $67.3 \%$ of FDN, and $40.2 \%$ of FDA [35]. The chemical composition of tropical grasses used in a system of production of livestock of double purpose in the northwest of Mexico, for guinea grass it was of $8.09 \%$ of raw protein, $11.5 \%$ of ash and $72.7 \%$ of FDN [36]. In another study, they found lower values from the guinea grass than those previously mentioned: raw protein $6.73 \%$, ash $8.37 \%$, FDN of $74.08 \%$ and FDA of $51.19 \%$ [37]. The value of raw protein obtained in the experiment is higher compared to the following data: $8.47 \%$ in sprout and $5 \%$ in growth of the pink grass [38].

\section{Conclusions}

The gramineous and leguminous components of the agrosilvopastoril system and the supplementation with nutritional blocks with $21 \%$ of protein improve the 
consumption of dry matter and allow bigger earnings of weight in goats in shepherding. In relation to the sex, with the males a value of $63.5 \pm 18.2 \mathrm{~g}$ is obtained day/animal and with the females of $54.25 \pm 17.3 \mathrm{~g}$ day/animal. Regarding the productive behavior, the creole goats in shepherding and supplemented with a nutritional block achieve a gain of weight of $70.5 \pm 20.3 \mathrm{~g}$ day/animal and without supplement of $47.29 \pm 18.9 \mathrm{~g}$ day/animal.

\section{References}

[1] Daskiran I, Savas T, Koyuncu M, Koluman N, Keskin M, Esenbuga N, Konyali A, Cemal İ, Gül S, Elmaz O, Kosum N, Dellal G, Bingöl M (2017) Goat production systems of Turkey: Nomadic to industrial Small Ruminant Research http://dx.doi.org/10.1016/j.smallrumres.2017.10.001.

[2] Food and Agriculture Organization Statistics (FAOSTAT) (2014) Food and Agriculture Organization Statistics. Food and Agriculture Organization Statistics (FAOSTAT), Rome, Italy Retrieved on 9th May 2016. faostat3.fao.org/home/E.

[3] Carrera, C (1971) Tipos de plantas que consume el ganado caprino. XII Informe de Investigación. División de Ciencias Agropecuarias y Marítimas. ITESM, Monterrey, N. L. pp. 168-169.

[4] Melechek JC y Leinweber CL (1972) Forage selectivity by goats an lightly and heavily grazed ranges. Journal of Range Management 25: 105-111.

[5] Franco-Guerra FJ, Sánchez M, Camacho JC , Hernández JE, Villarreal OA , Rodríguez E. L, Marcito O (2014) Consumption of tree species and shruns for fruits and herbaceous goats trashumance grazing in Mixteca oaxaqueña Mexico. Tropical and Subtropical Agroecosystems, 17: 267270.

[6] Devendra, C (1977) Studies in the intake and digestibility of two varieties of Quinoa Grass by goats and sheep. A long grass Mardi England Research Bull. Nro 140. pp. 22-29.

[7] Azócar CP, D’Herbes JM y Díaz SJ (1987) Estudio de sistemas de pastoreo con caprinos para el secano árido de la IV Región de Coquimbo. Dieta e índices de aceptabilidad relativa de arbustos. Avances en Producción Animal-12 (1-2): 35-47.

[8] Milián-García I, Sánchez-Cárdenas S, Wencomo-Cárdenas HB, Ramírez-Suárez WM and Navarro-Boulandier M (2018) Study of biodiversity components in the agroecological farm La Paulina, Perico municipality, Cuba. Pastos y Forrajes 41 (1): 50-55.

[9] Arciniegas-Torres SP, Flórez-Delgado DF (2018) Study of silvopastoral systems as an alternative for the sustainable management of livestock Ciencia y Agricultura . 15 (2): 107116. http://doi.org/10.19053/01228420.v15.n2.2018.8687.

[10] Altieri M (1996) Agroecología y agricultura sostenible. Módulo 1 Agroecología. Bases históricas y teóricas. CLADES. Lima. Perú. 51 p.

[11] Monzote, M (2005) Agroecología y agricultura orgánica para la sostenibilidad. En: Memorias del Congreso Internacional Producción Animal Tropical. Las ciencias técnicas y agropecuarias por un desarrollo sostenible. Universidad de Camagüey. Camagüey, Cuba.

[12] Ørskov, EB (2005) Silvopastoral systems: technical, enviromental and socio-economic challenges. Rev. Estación Experimental. Pastos y Forrajes. Indio Hatuey, 28 (1): 5-9.

[13] López OJA y Ramos MM (2004) Frecuencia de parásitos gastroentéricos en caprinos de la cabecera municipal de Piaxtla, Puebla. XXVIII Congreso Buiatria. Memorias. Michoacán. México.

[14] Sánchez, T (2006) Diagnóstico productivo para sustentar las unidades de producción familiar caprinas en la Mixteca Poblana: Tehuaxtla y Maninalcingo. Tesis de Licenciatura. EMVZ BUAP. Tecamachalco. Puebla. México.

[15] Castro SDD, Guimarães JR, Vilelab L, Alcantara MG , Fernandes de Souza FA (2018) Implementation of silvopastoral systems in Brazil with Eucalyptus urograndis and Brachiaria brizantha: Productivity of forage and an exploratory test of the animal response. Agriculture, Ecosystems and Environment. https://doi.org/10.1016/j.agee.2018.07.017.

[16] Vargas, SL (2003) Análisis y desarrollo del sistema de producción agrosilvopastoril caprino para carne en condiciones de subsistencia de Puebla, México. Universidad de Córdoba. Facultad de veterinaria. 150 p.

[17] Araque C, D’Aubeterre R, Quijada T, Dickson L, Muñoz G y Sánchez A (2008) Efectos de la complementación con henomelaza-urea sobre parámetros productivos en cabras criollas a pastoreo. Revista Científica FCV-LUZ 18 (4): 398-402.

[18] Vásquez, ANC (2014) Determinación de fracciones de carbohidratos y proteínas y del valor nutricional de pasto Buffel (Cenchrus ciliaris L.) asociado con dos subproductos agroindustriales. Maestría en Ciencia Animal. Posgrado Conjunto Facultad de Agronomía y Medicina Veterinaria y Zootecnia. Universidad Autónoma de Nuevo León. pp. 3472 .

[19] Romero ME, Gutiérrez E, Bernal H, Morales H, Colin J, Olivares E, Gutiérrez O, Torres V y Dennis H (2007) Estacionalidad en la concentración de metabolitos sanguíneos de vacas Charolais y Beefmaster en pastoreo de zacate Buffel en el noreste de México. Revista Cubana de Ciencia Agrícola. 41 (3): $237-242$.

[20] Arias ME, González-Pérez JA, González-Vila FJ, Ball AS (2005) Soil health - A new challenge for microbiologists and chemists. International microbiology. 8: 13-21.

[21] Herrera MCA, Rosales MJM y González GA (2008) Crecimiento pre y posdestete en cabras Boer x Boer y Boer $\mathrm{x}$ Nubia en el altiplano mexicano. Centro de Mejoramiento Genético Caprino. Gobierno del Estado de San Luis Potosí. Unidad Regional Universitaria de Zonas Áridas. Universidad Autónoma Chapingo. A. P. 8, Bermejillo, Durango, México. Revista Chapingo Serie Zonas Áridas. 7: 125-132.

[22] Karua SK y Banda JW (1992) Dairy goat breeding in Malawi: Gestation length, birthweigths and growth of the indigenous goats and the Saanen crosses. Revista Chapingo Serie Zonas Áridas. 2008. 7: 125-132 132 Bunda College of Agriculture. Lilongwe, Malawi.

[23] Hafez ESE y Dier IA (1972) Desarrollo y nutrición animal. Ed. ACRIBIA. Zaragoza España. p 22. 
[24] Bussetti MR, Babinec F, Suárez J, Víctor H, Bedotti D (2006) Peso al nacimiento y crecimiento hasta el destete de corderos Pampinta y sus cruzas con Ile de France y Texel. Revista de Investigaciones Agropecuarias, ISSN 1669-2314.35 (2): 91101.

[25] Rojas H, Coronado L y Hurtado E (2005) Evaluación de la suplementación proteica durante el crecimiento post destete de corderos a pastoreo. Universidad de Oriente. Escuela de Zootecnia, Campus Los Guaritos. Maturín, Estado Monagas, Venezuela. Revista Zootecnia Tropical. 23 (3): 0798-7269.

[26] Guioffredo JJ y Petryna A (2010) Caprinos: generalidades, nutrición, reproducción e instalaciones. Universidad Nacional de Río Cuarto. Facultad de Agronomía y Veterinaria Departamento de Producción Animal. Río Cuarto, Argentina. $20 \mathrm{p}$.

[27] Zavala, RE (2002) Elaboración rústica y uso de bloques de proteína en ganado caprino. Universidad Autónoma Agraria Antonio Narro. Buenavista, Saltillo, Coahuila, México. 45 p.

[28] Vázquez MP, Castelán OOA, García MA y Avilés NF (2012) Uso de bloques nutricionales como complemento para ovinos en el trópico seco del altiplano central de México. Tropical and Subtropical Agroecosystems. 15 (1): 87-96.

[29] Estrada, PM (2001) Bloque multinutricional con diferentes niveles de proteína no degradable como suplemento en la alimentación de ovinos. Tesis de Maestría en Ciencias. Posgrado en Producción Animal. Universidad Autónoma Chapingo. Chapingo Estado de México. pp. 37-64

[30] Birbe B, Herrera P, Colmenares O y Martínez N (2006) El consumo como variable en el uso de bloques multinutricionales. Seminario de Pastos y Forrajes. Maracaibo, Venezuela. pp. 43-61.

[31] Briske DD, Derner JD, Brown JR, Fuhlendorf SD, Teague WR, Havstad KM, Guillen RL, Ash AJ and Willms WD (2008) Rotational grazing on rangelands: Reconciliation of perception and experimental evidence. Rangeland Ecology and Management 61 (1): 3-17.
[32] Rodríguez FG y Roncallo FB (2013) Producción de forraje y respuesta de cabras en crecimiento en arreglos silvopastoriles basados en Guazuma ulmifolia, Leucaena leucocephala y Crescentia cujete. Corporación Colombiana de Investigación Agropecuaria, Alimentación y Nutrición Animal. pp. 77-89.

[33] Vergara LJ, Rodríguez PA, Navarro C y Atencio A (2006) Efecto de la suplementación con Leucaena (Leucaena leucocephala Lam. de Wit) sobre la degradabilidad ruminal del pasto alemán (Echinochloa polystachya H. B. K. Hitch). Revista Científica FCV-LUZ, 16 (6): 642-647.

[34] Bugerín J, Lemus C, Sangines L, Aguirre J, Ramos A, Soca M y Arece J (2009) Evaluación de dos especies de Leucaena, asociadas a Brachiaria brizantha y Clitoria ternatea en un sistema silvopastoril de Nayarit, México. Revista Científica Pastos y Forrajes. 32 (4): 1-9.

[35] Suárez PE, Reza GS, García CF, Pastrana VI y Díaz AE (2011) Comportamiento ingestivo diurno de bovinos de ceba en praderas del pasto Guinea (Panicum maximum cv. Mombasa). Revista Corpoica - Ciencia y Tecnología Agropecuaria. 12 (2): 167-174.

[36] Juárez RAS, Cerrillo SMA, Gutiérrez OE, Romero TEM, Colín NJ y Bernal BH (2009) Estimación del valor nutricional de pastos tropicales a partir de análisis convencionales y de la producción de gas in vitro. Técnica Pecuaria en México. 47 (1): 55-67.

[37] León CFA y Talavera TJC (2012) Composición química de la biomasa verde del pasto Guinea (Panicum maximum, Jack) CV Colonial, con diferentes niveles de inclusión de urea. Finca Santa Rosa, Sabana Grande, Managua. Universidad Nacional Agraria, Facultad de Ciencia Animal. Managua, Nicaragua. pp. 1-13.

[38] Melgoza CA, Balandrán VMI, Mata R, González MR y Pinedo AC (2014) Biología del pasto rosado Melinis repens (Willd.) e implicaciones para su aprovechamiento o control. Revista Mexicana en Ciencias Pecuarias. (4): 429-442. 